ח

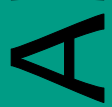

n

Ш

Z

O

$\underline{-}$

$F$

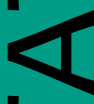

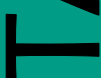

ه

Ш

n

n

$\overline{0}$
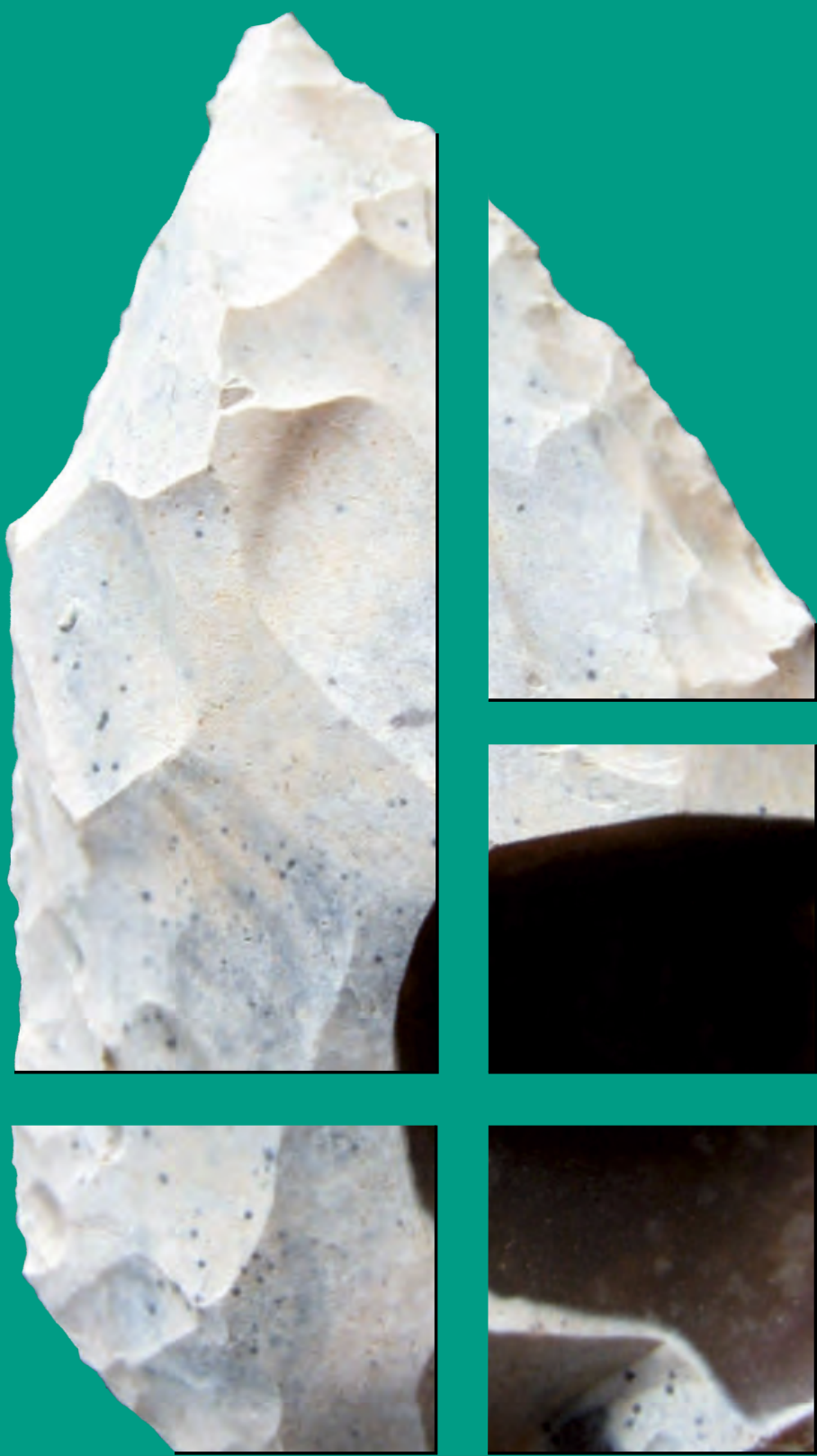

Ser. 3. No.9.| 2021 


\section{Dissertationes Archaeologicae ex Instituto Archaeologico}

Universitatis de Rolando Eötvös nominatae

Ser. 3. No. 9.

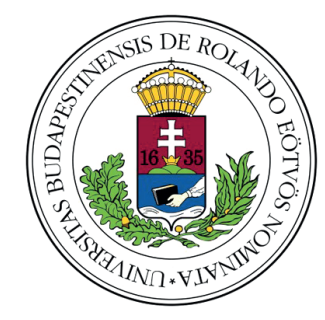

Budapest 2021 


\section{Dissertationes Archaeologicae ex Instituto Archaeologico Universitatis de Rolando Eötvös nominatae}

Ser. 3. No. 9.

Editor-in-chief

Dávid BARTus

Editorial board

László Bartosiewicz (Stockholm University, Stockholm)

Ondřej Chvojкa (University of South Bohemia, České Budějovice)

Zoltán Czajlik (Eötvös Loránd University, Budapest)

Mario Gavranović (Austrian Arhaeological Institute AAS, Vienna)

Hajnalka Herold (University of Exeter, Exeter)

Klára Kuzmová (University of Trnava, Trnava)

Tina Milavec (University of Ljubljana, Ljubljana)

Gábor V. Szabó (Eötvös Loránd University, Budapest)

Tivadar VIDA (Eötvös Loránd University, Budapest)

Technical editor

Gábor VÁcZI

Proofreading

Eszter TímÁr

Strobe DrIVER

Borbála MoHÁcsI

Fruzsina NÉMETH

Eli J. S. WeAVERDYCKE

Aviable online at http://ojs.elte.hu/dissarch

Contact: dissarch@btk.elte.hu

ISSN 2064-4574 (online)

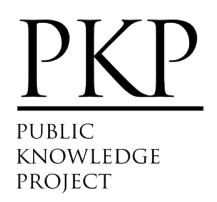

(c ELTE Eötvös Loránd University, Institute of Archaeological Sciences

Layout and cover design: Gábor Váczi

Budapest 2021 


\section{CONTEnTs}

\section{ARTiCles}

Attila PÉNTEK - Norbert FARAgó

Palaeolithic and Mesolithic assemblages from Tunisia

Attila PÉNTEK - Norbert FARAGó

Some remarks on a German chipped stone lithic assemblage of uncertain origin in the collection of the Institue of Archaeological Sciences, Eötvös Loránd University

László Gucsi

Technological observations on a Late Copper Age ceramic assemblage

from Hódmezővásárhely-Kopáncs-Olasz-tanya, Hungary

János Gábor TARBAY

101

A Koszider Period Sword from Tornyospálca-Sírkútgaz (Szabolcs-Szatmár-Bereg County, Hungary)

Ábel GARCZIK

Dolia in the Middle La Tène Period of the Carpathian Basin in the light of new finds from Perkáta-Nyúli-dűlő

Lajos JuHÁsz

An exceptional Sarmatian cast medallion with star and crescent

Gabriella G. DeLBó

New data on the Pannonian glazed casserole handles

Csilla SÁró

The fibula production of Brigetio: Model, semi-finished products, and failed castings

Anita BENES

New data on the capacity of the Roman aqueduct of Brigetio

Melinda SzABó

Status or Role? Differences between the Social Status and Role in Brigetio

Krisztina HoppáL

Roman engraved gems from Southeast Asia 


\section{FiELD REPORTS}

Bence SIMON - Ferenc BARNA

Another barrel-lined well a road section and late Roman graves from Brigetio

Rita RAKONCZAY

Trial excavations in mediaeval churches of Kishartyán, Kisterenye, Mátranovák and Szuha in Nógrád County 2021

\section{Thesis Review Articles}

Tamás KEszi

The change of the pottery style of the Mako and Nagyrév cultures in the Early Bronze Age:

The settlement in Iváncsa-Lapos

Linda Dobosi

Building techniques and building materials in Brigetio:

With the virtual reconstruction of House I/a of the civil town of Brigetio

Csilla SÁRó

Tradition and Romanization by the attire of the Eraviscus tribe 


\title{
Status or Role?
}

\section{Differences between the Social Status and Role in Brigetio}

\author{
Melinda Szabó \\ MTA - ELTE Research Group for Interdisciplinary Archaeology \\ szabo.melinda@elte.btk.hu
}

Received 11 December 2021 | Accepted 21 December 2021 | Published 2 March 2022

\begin{abstract}
The social structure of the Roman Empire had its own strict rules and legal restrictions, which defined one's possibilities in society. Despite these rules, on some occasions, people had the opportunity to obtain a higher role than their social status, or on the contrary, they never reached the role they were legally allowed. The fluctuation between social groups could be vertical, but in the case of military personnel, it was rather horizontal. In all instances, money was an important component during changes in status, but personal influence was also non-negligible. In this paper, a few examples are presented of this phenomenon from the provincial context of the civil town of Brigetio. Higher social groups are represented by the two equestrians and decurions, while an Augustalis and a slave are introduced from the lower social strata.
\end{abstract}

Keywords: Brigetio, ordo equester, decurio, libertus, slave

\section{Introduction}

This paper ${ }^{1}$ presents a survey about some examples of the fact, that classes in Roman society were not as closed units as sometimes they seem to be. As G. Alföldy stated, the social structure of the Empire could be represented as a pyramid, but constant fluctuation was also its characteristic feature. ${ }^{2}$ Based on this statement, I aimed to find direct examples of this fluctuation in the provincial context. My examples stem from Pannonia, from the town of Brigetio.

In my research, I have focused and dealt with only the civilian inhabitants of the town mentioned in epigraphic sources, which means 413 people. This number contains also a few military personnel, those who had a connection with the civilian life of the town, had a family or civilian duty there.

Examples of the fluctuation between different social groups could be observed clearly among equestrians and decurions. Finding examples among the Augustales was not unexpected, because the whole concept of the group was based on the difference between its members' social status as liberti and the role they could afford thanks to their wealth. ${ }^{3}$ Because of this, one could list all of them as examples of the difference between social status and role, but in my paper, I only mention one of them, as an example. The most peculiar example is the case of a slave, who clearly had a more important role in town than what his social status suggested.

1 The research was supported by the UNKP-21-4 New National Excellence Program of Ministry for Innovation and Technology from the source of the National Research, Development and Innovation Fund.

2 AlföLDY 1988, 146-147.

3 Alföldy 1988, 131. 


\section{Equestrian decurions}

No members of the highest social groups (the imperial family and senators) are known from Brigetio in a civilian context. The number of equestrians was also surprisingly low, only two people known from the equestrian order, ${ }^{4}$ except military personnel of course. The two equestrians from Brigetio were decurions at the same time. This situation was not extraordinary in the Roman Empire, members of the ordo equester often got stuck in lower, not equestrian positions. ${ }^{5}$

The name of one of the two equestrian-decurions has not endured, and a significant question emerges about his inscription. ${ }^{6}$ In the first remaining line of the inscription, the word decurion is just a completion without any remaining letters from the word. Before the expression municipium Brigetionensium a few other possibilities are also conceivable. ${ }^{7}$ The most probable completion regarding the inscriptions in footnote 4, is a decurion (or higher, like duumvir) function, the Augustalis title seems unlikely, because of the equestrian carrier. But we cannot pronounce it without a little doubt. After all, this man's carrier could be particular, because most equestrian-decurions had no opportunity to fulfil any post of the tres militiae equestres, but this anonymous man completed it. Although in the end he also remained without any higher positions in civil service. The other equestrian-decurion of Brigetio was called Titus Flavius Crispinus. People bearing the Flavia gentilicium settled in Brigetio after the Marcomannic wars came from the region of Lake Neusiedl (Ferto). ${ }^{8}$ We know from this territory, from the civil town of Carnuntum, another equestrian-decurion with the gentilicium Flavius, but in general, the presence of the Flavii among the decurions was not typical neither in Carnuntum nor in Brigetio. ${ }^{9}$ L. Barkóczi stated that there was no important Flavian family in Brigetio. ${ }^{10}$ However, from the two equestrians in civil administration, one was a Flavius, so this statement should be reconsidered.

In the case of the equestrian-decurions, their social-political status was definitely higher as members of the equestrian order than their role in civil life, which was exactly the same as all decurions'.

4 AE 1971, 0319. ------] / [dec(urio)] mun[ic(ipii)] / [B]rig(etionensium) a mi[li]/[t]i(i)s qui e[q(uestrem) $\mathrm{m}($ ilitiam)] / [pe]t(it) templum / a fundame[n]/ [t]is extru[xit] / [------

CIL 03, 10534. D(is) T(iti) Fl(avi) Crispini M(anibus) / dec(urionis) mun(icipii) Brig(etionis) eq(uo) pub(lico) / et Ulp(iae) Gemellinae / matris eius / T(itus) Fl(avius) Eutyches / libertus et heres.

5 The decurion officers of the municipia and coloniae had a better chance of becoming an equestrian. Giving them higher rank and positions was a practical choice, because they were already experienced in administration, and they were accepted by the locals. In the long run, they were perfect for procuratorial duties (DEviJver 1999, 243). But regarding the number of available equestrian positions in the Empire, most of the equestrians elevated from decurions were not able to reach a higher position, and they remained in municipal offices, like decurions, but with the status of an equestrian (AlFöLDY 1981, 179; IJSEWIJN 1984, 43).

6 See footnote 4

7 Concurrent inscriptions to decurio municipii Brigetionensium: AE 2006, 1043; CIL 03, 04388; AE 2013, 1377; CIL 03, 04294; CIL 03, 04336; RIU 0601; RIU 0603; AE 2006, 1047; CIL 03, 10534.

Other functions appear with municipii Brigetionensium: Ivir quinquennalis municipii Brigetionensium: AE 2006, 1049. Augustalis municipii Brigetionensium: AE 1984, 0723; AE 1962, 0043; RIU 0516; RIU 0377; CIL 03, 11027; AE 1997, 1267; CIL 03, 04330; CIL 03, 04323; CIL 03, 11045.

8 BARKóczi 1964, 272. This area was part mostly of the territory of Carnuntum, the other parts of it belonged to Scarbantia (BARKóczi 1964, 267).

9 BARKóczi 1964, 267; 272. It is possible, that Flavius Crispinus arrived from the same territory, but this does not prove that the two Flavian equestrian-decurion had any relations towards each other. BARKóczI 1964. 272. 


\section{Decurions}

In the provinces, the ordo decurionum consisted of three main groups at the time of the town's foundation. First, the indigenous elite of the province, ${ }^{11}$ second, the civil Romans arriving during and after the Roman conquest, ${ }^{12}$ third, the veterans of the deducted legions ${ }^{13}{ }^{13}$ In Brigetio we should suppose that the veterans had a leading role in the settlement's life, because of the presence of the legion, and the fact that Brigetio became a municipium just at the beginning of the $3^{\text {rd }}$ century, ${ }^{14}$ so indigenous elements or conquerors were out of the question for this period. The status and prestige of military personnel were different in the provinces, but right in frontier zones and near legionary camps they were highly appreciated. ${ }^{15}$ Even so, surprisingly, there were only two veteran $\mathrm{s}^{16}$ among the decurions ${ }^{17}$ of the civil town in Brigetio, but this pattern is not without precedent. ${ }^{18}$ Across the Empire, on the one hand, only the higher military officers had enough money ${ }^{19}$ to get into the ordo decurionum ${ }^{20}$ on the other hand, veterans were usually not interested in political service. ${ }^{21} \mathrm{We}$ could not tell whether Lucius Valerius Rufus was a higher officer or not because in his inscription only the fact was written that he was a veteranus of the legio I Adiutrix. ${ }^{22}$ Marcus Valerius Marinus was a signifer, which means he belonged to the principales and received a higher salary than the average legionary. ${ }^{23}$ These two inscriptions are dated before the $3^{\text {rd }}$ century, suggesting that for veterans to become a decurion was an opportunity before the prosperity in Pannonia under the Severan dynasty. To justify the motive whether it became more difficult after the Severan era for veterans to get a role in civil administration or it was a simple choice of theirs, requires further research.

All in all, in these cases, the former military officers had enough money to play a higher role in the community, but their social status was not high enough for them as military persons. But, as the structure was permeable, these two men could find a way to reach a higher social status in civil life using their money and role after their military careers.

\section{Augustales}

As I alluded to in the introduction, the Augustales were an equally wealthy social group to the decuriones, but because of their slave origins, they had no opportunity to be a legal decurion. ${ }^{24}$

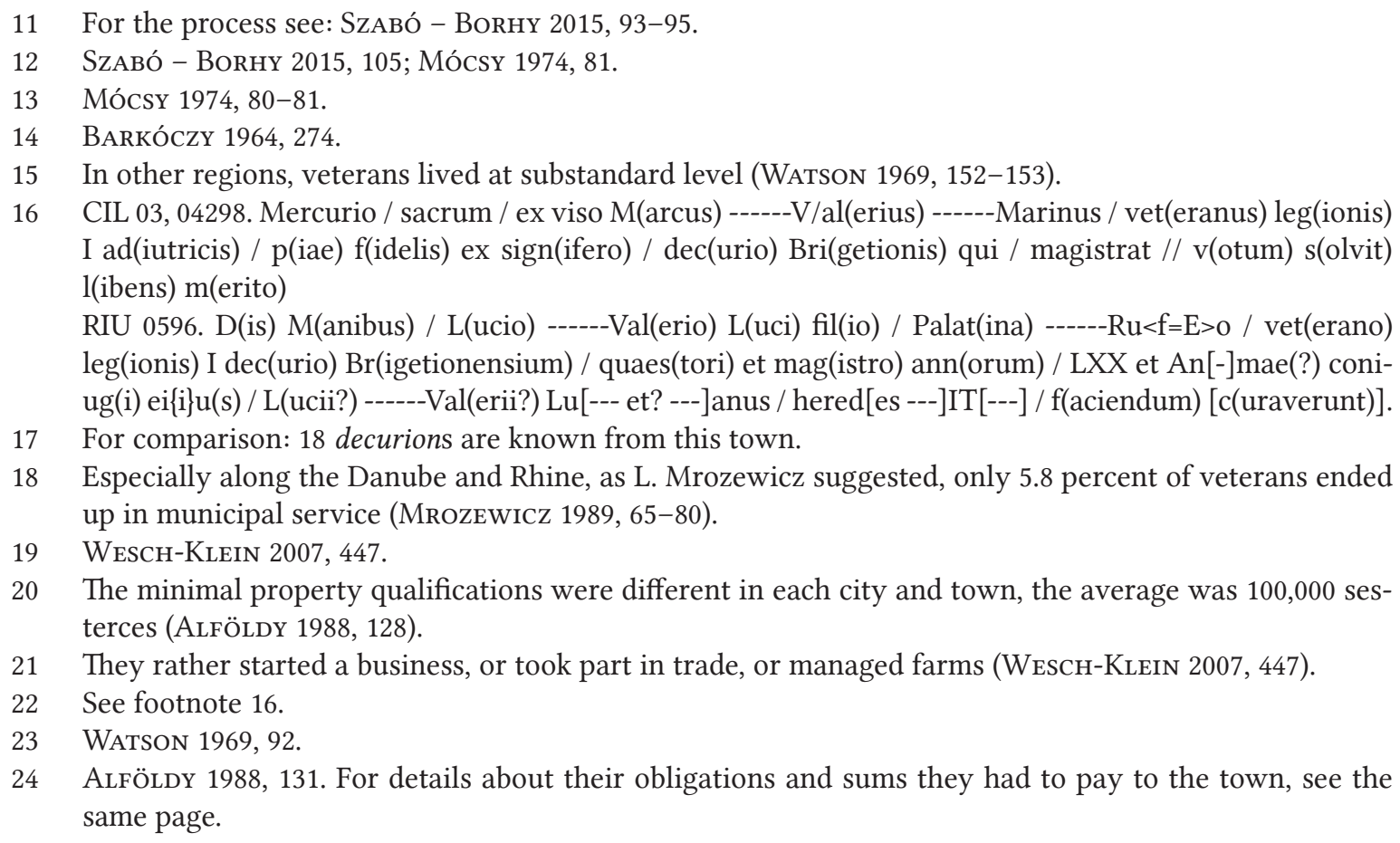

18 Especially along the Danube and Rhine, as L. Mrozewicz suggested, only 5.8 percent of veterans ended up in municipal service (MrozEwiCz 1989, 65-80).

19 WeSCH-KLEIN 2007, 447.

20 The minimal property qualifications were different in each city and town, the average was 100,000 sesterces (AlFöLDY 1988, 128).

21 They rather started a business, or took part in trade, or managed farms (WESCH-KLEIN 2007, 447).

22 See footnote 16.

23 WATSON 1969, 92.

24 Alföldy 1988, 131. For details about their obligations and sums they had to pay to the town, see the same page. 
Becoming an Augustalis was a possibility to circumvent the standard social structure for them and to have a more important role thanks to their wealth than what their legal status could provide. It is proven that the Augustales in Pannonia were considerably rich and had a dominant role in the life of towns. ${ }^{25}$

I detected 10 Augustales from Brigetio, ${ }^{26}$ their background motive could be exactly the same I stated above. As a concrete reference, the family of the $\mathrm{Titii}^{27}$ is observable. They were a typical rich libertus family, whose wealth rested on trade. ${ }^{28}$ The father of the family was an Augustalis, which means he was a libertus who had sizable possessions. The inscription says Titius Domninus had lost two sons, one of them was a negotians and had been killed maybe during his travels for the carried money or wares ${ }^{29}$ Having a negotians in the family proves that their wealth came from trade,$^{30}$ although the libertus origin of the father did not let him reach a higher status than that of an Augustalis. As his descendants had died, the family could not reach the status of decurions, although Titius Domninus' sons could have had the right and wealth for that.

\section{Slaves}

The slave Primitivus left behind two inscriptions. ${ }^{31}$ One of them mentions Primitivus evidently as a slave (CIL 03, 04288.). He was the vilicus of the conductor Iulius Proclus. The rest of the vilicus inscriptions known from Pannonia came to light at Poetovio. ${ }^{32}$ But there is no doubt about Brigetio as the home of Primitivus because he erected the second inscription (a sarcophagus, RIU 0575.) to his beloved wife in this town. In this second inscription, he did not refer to himself as a slave, but we can assume that the Primitivus in this second inscription is the same slave, because of the lack of the gentilicium and the similar field of duty in the two cases.

AlFÖlDY 1958, 439.

AE 1962, 0043; AE 1944, 0108; AE 1944, 0110; AE 1944, 0119; AE 1997, 1267; CIL 03, 11007; CIL 03, 04330; CIL 03, 04323; CIL 03, 11045; CIL 03, 11044.

CIL 03, 11045. Memoria[e T]iti q(uondam) / Domnini sive P/asseris nego/tianti splend/ido qui vixi/t annis XXVI / [i]nterfect/o a barbari/s T[i]tius // Domninu[s] / pater infelix / filiorum [i]n / hoc sarco/fago duo / corpora / posuit // in m[emo]riam T[i]t[i] Ursinia/ni qui [vixit] ann(os) XVIII Tit/ius Domninus august(alis) / municipi(i) Br[i]g(etionensium) filio pien/tissimo fac[i]endum / curav[i]t //

For the liberti's role in trade and commerce, see: D'Arms 1981; Hopkins 1978; GARNSEY 1981; BroEKAERT 2016.

The inscription says he was killed by barbarians, but by a concurrent inscription these barbarians could be interpreted as muggers, too. The concurrent inscription is AE 1903, 0203. L(ucio) Atilio L(uci) l(iberto) / Saturnino / annor(um) XL domo / Fl(avia) Scarbantia ------interfect(o) a ------latronibus inrtusis(!) / Atilius Tertius frater / et Statius Onesimus / amico / loc(us) gratuit(um) dat(um) ab / Clodia Tertia. In this case the deceased was killed for the same reason as the negotians in the example (KovÁcs 2018, 302-303).

30 The exact meaning of the world negotiator/negotians is still under determination. But all sources agrees with that the negotiatores had complex role in business, and they had way much more money and opportunities than a simple salesman (Verboven 2007, 99-113; Feuvrier-Prévotat 1981, 396; LAST 2021).

31 CIL 03, 04288. Genio com/merci et ne/gotiantium / Primiti(v)us / Iuli Procli / cond(uctoris) VIII ser(vus) / vil(icus) XX.

RIU 0575; Borhy 2006, 36-37. Matronae innocen/tissimae Ael(iae) Valerian(a)e coniug(i) Primiti(v)us / actor octavar(um) con/iugi carissimae.

SzABó 2021, 177. 
Primitivus was a customs officer in Brigetio ${ }^{33}$ his role was to collect and supervise the customs process from the Barbaricum towards the Roman Empire. ${ }^{34}$ The 'vilicus $X X$ ' was also explained as the collector of the vicesima hereditatium, ${ }^{35}$ but it seems unlikely. Various types of taxes were $5 \%$, including inheritance tax, the tax that was obligatory at manumission (vicesima libertatis), and import customs at the riverside frontiers of the Roman Empire (as a form of portoria). ${ }^{36}$ The aforementioned altar (CIL 03, 4288.) was erected to the Genius of commerce and negotiation, which could also be an argument on behalf of the vicesima as import duty. Moreover, from the territory of the Publicum portorium Illyrici, where Brigetio was located, a few mentions of the vicesima hereditatium was preserved. In these cases, the world 'hereditatium' was also written in stone as refinement (CIL 03, 1996, Salona; CIL 03, 482, Virunum; CIL 03, 4064, Poetovio). Above all, the mentioned master of the slave, Iulius Proclus was the publican of the vectigal (see CIL 03, 4288.), we can assume that he was in charge also in the collection of portorium, and the custom was part of that. On the other inscription (RIU 0575) Primitivus was referred to as actor octavarum. It means that later or earlier than being a vilicus, he also fulfilled the role of collecting the vectigal.

These two positions provided an important role to Primitivus in the everyday life of Brigetio. As a customs officer, he had the opportunity to sabotage or help someone's economic interests, and as the collector of land taxes, he could also exercise an influence on the landowners of the settlement. Despite these roles and opportunities, he was just a slave regarding his social status. On the one hand, as a slave, he had no rights and should have been excluded from the higher social groups, but his roles in commerce and taxation could provide him with some advantages. To understand his appreciation in society, we should take a look at his marriage. Slaves had no right to legally marry, although the masters could allow their slaves to wed. ${ }^{37}$ The phenomenon was not unusual in the habits of the Roman Empire, slave-marriages are well known both in the works of ancient authors and epigraphic records. ${ }^{38}$ The particularity of the marriage of Primitivus and Aelia Valeriana is the difference in social status between the two members. It seems Aelia Valeriana was a Roman citizen and her husband was a slave. This marriage was a considerable downgrade in social status for Aelia Valeriana, considering the senatus consultum Claudianum categorized the ingenuae living with a slave as servae or libertae. ${ }^{39}$ As this marriage shows us, Primitivus' appreciation was much higher, than the average slaves'. Maybe his wealth and the potency he had in the settlement thanks to his role as a customs officer and collector of land-taxes provided him with a higher role in the everyday life of Brigetio than a simple slave could have had.

\section{Summary}

As the listed examples show, the Roman social structure was on the one hand a strict system with legal restrictions, but at the same time in personal cases, one could find a way to act above his social status, or in contrary, despite the social status, one could not reach a matching role. The equestrian

33 Brigetio's role in trade based on its geographical conditions, as located along the river Danube at the firth of the river Vág at the frontier between the Romans and German tribes, furthermore the legionary camp of the legio II Adiutrix provided a huge demand.

34 ØRSTED 1985, 286. The vilicus XX was also explained as the collector of the vicesima hereditatium (BORHY 2006, 36, followed by Havas 2013, 71), but it seems unlikely.

35 Borhy 2006, 36, followed by Havas 2013, 71.

36 De LAET 1949, 243.

37 Although the legal matrimonium was not an option for slaves, in the case of contubernium the words uxor, maritus, filius etc. were used (WEAVER 1974, 128).

38 BRADLEY 1987, 47-50.

39 WeAVER 1974, 125-126. 
decurions had a higher status than their role, meanwhile, the slave could have a higher role than his social standing. The case of military personnel could not be determined as a higher or lower role. They changed their military status to a civil role, which required a legal status as a decurion too. Their lives are examples of the possibility of changes in social structure, but also emphasize that money was the base of changes like that. The Augustales were in a similar situation to these two veterans. For them, the wealth of the family was the key to the role they had in Brigetio.

\section{References}

AlföLDY, G. 1958: Augustalen- und Sevirkörperschaften in Pannonien. Acta Antiqua Academiae Scientiarum Hungaricae 6, 433-459.

ALFÖLDY, G. 1981: Die Stellung der Ritter in der Führungsschicht des Imperium Romanum. Chiron 11, 169-215.

ALFÖLDY, G. 1988: The Social History of Rome. London.

Barkóczi, L. 1964: The population of Pannonia from Marcus Aurelius to Diocletian. Acta Archaeologica Academiae Scientiarum Hungaricae 16, 257-356.

BorHy, L. 2006: Vezető Komárom város római kori kóemlékeihez. Acta Archaeologica Brigetionensia 1/5. Komárom.

BradLeY, K. R. 1987: Slaves and Masters in the Roman Empire. A Study in Social Control. New York.

BroekAert, W. 2016: Freedmen and Agency in Roman Business. In. Wilson, A. - Flohr, M. (eds): Urban Craftsmen and Traders in the Roman World. Oxford Studies on the Roman Economy. New York. 222-253. DOI: 10.1093/acprof:oso/9780198748489.003.0011

D'Arms, J. H. 1981: Commerce and Social Standing in Ancient Rome. Cambridge. Dor: 10.4159/harvard. 9780674331198

De Laet, S. J. 1949: Portorium. Étude sur l'organisation douanière chez les Romains surtout à l'époque du Haut-Empire. Brügge.

Devijver, H. 1999: Les relations sociales des chevaliers Romains. In: Demougin, S. - Devijver, H. - Raepsaet-Charlier, M.-Th. (eds): L'Ordre équestre. Histoire d'une aristocratie (IIe siècle av. f.-C. - IIIe siècle ap. 7.-C.). Actes du colloque, Bruxelles-Leuven, 5-7 Octobre 1995. Rome, 237-269.

Feuvrier-PrÉvotat, C. 1981: Negotiator et mercator dans le discours cicéronien: essai de définition. Dialogues d'histoire ancienne 7, 367-405. DOI: 10.3406/dha.1981.1443

Garnsey, P. 1981: Independent Freedmen and the Economy of Roman Italy under the Principate. Klio 63, 359-371. DOI: 10.1524/klio.1981.63.12.359

HavAs, Z. 2013: A publicum vicesimae libertatis bronz bélyegzője Aquincumból. Studia Epigraphica Pannonica $5,59-106$.

Hopkins, K. 1978: Conquerors and Slaves. Sociological Studies in Roman History. Vol. 1. Cambridge, 1978.

IJSEWIJN, E. 1984: Gli ordines decurionum come base di reclutamento delle militiae equestres sotto il Principato. Bulletin de l'Institut Historique Belge de Rome 53-54, 41-63.

KovÁcs, P. 2018: Interfectus a latronibus intrusis. Beiträge zum Tod eines Freigelassenen aus Scarbantia. In: Nemeth, E. (Hrsg.): Violence in Prehistory and Antiquity - Die Gewalt in der Vorgeschichte und im Altertum. Kaiserslautern-Mehlingen, 301-318.

LAST, R. 2021: A Fictive Membership Rush and Curatorial Fraud in the Lex of the Collegium of Ivory and Citrus-Wood Merchants (CIL 6.3385 = ILS 7214). The Classic Quarterly 71:1, 347-358. Dor: 10.1017/ S0009838821000392

Mócsy, A. 1974: Pannonia a korai császárság idején. Budapest. 
Mrozewicz, L. 1989: Die Veteranen in den Munizipalräten an Rhein und Donau zur hohen Kaiserzeit (I-III. Jh.). Eos 77, 65-80.

ØRSTED, P. 1985: Roman Imperial Economy and Romanization. A study in Roman imperial administration and the public lease system in the Danubian provincies form the first to the third century A.D. Copenhagen.

SzABó, M. - Borhy, L. 2015: Magyarország története az ókorban: Kelták és rómaiak. Budapest, 2015.

SzABó, M. 2021: Pannonia kereskedelmének társadalmi háttere. PhD Dissertation, Eötvös Loránd University, Budapest.

Verboven, K. 2007: Ce que negotiari et ses dérivés veulent dir. In: Anderau, J. - Chankowski, V. (eds): Vocabulaire et expression de l'économie dans le monde antique. Bordeaux, 89-118. Dor: 10.4000/books.ausonius. 4214

Watson, G. R. 1969: The Roman Soldier. Bristol.

Weaver, P. R. C. 1974: Social Mobility in the Early Roman Empire: The Evidence of the Imperial Freedmen and Slaves. In: Finley, M. I. (ed.): Studies in Ancient Society. London, 121-140.

Wesch-Klein, G. 2007: Recruits and Veterans. In. Erdkamp, P. (ed.): A Companion to the Roman Army. Oxford, 435-450. DOI: 10.1002/9780470996577.ch25 
